\title{
Materiovigilance: Concept, Structure and Emerging Perspective for Patient's Safety in India
}

\author{
Authors \\ Farazul Hoda', Rishabh Verma', Mawrah Arshad', Ali Nasir Siddiqui' ${ }^{2}$, Mohammad Ahmed Khan', \\ Mohammad Akhtar' ${ }^{\mathbb{D}}$, Abul Kalam Najmi ${ }^{1}$
}

\begin{abstract}
Affiliations
1 Department of Pharmacology, School of Pharmaceutical Education and Research, Jamia Hamdard, New Delhi, India

2 Department of Pharmaceutical Medicine, School of Pharmaceutical Education and Research, Jamia Hamdard, New Delhi, India
\end{abstract}

\author{
Key words \\ diagnostics, adverse drug reactions, drug regulation, drug \\ research
}

$\begin{array}{ll}\text { received } & 07.02 .2020 \\ \text { accepted } & 29.05 .2020\end{array}$

Bibliography

DOI https://doi.org/10.1055/a-1195-1945

Published online: 3.8.2020

Drug Res 2020; 70: 429-436

(c) Georg Thieme Verlag KG Stuttgart · New York

ISSN 2194-9379

\section{Correspondence:}

Prof. Abul Kalam Najmi

Department of Pharmacology, School of Pharmaceutical

Education and Research

Jamia Hamdard

New Delhi 110062

India

Tel.: + 91-9891220056

aknajmi@jamiahamdard.ac.in

\begin{abstract}
There has been an escalation in the number, diversity, and complexity of medical devices. Regulation of these devices has also advanced due to the requirement of better regulatory perspective induced due to elevation in the number of adverse events associated with medical devices. All over the globe, various measures are undertaken to provide better safety to the patients along with attempts to improve the standard of medical devices. The initial and ultimate objective of the concept happens to be unfailingly to ensure patient safety as well as impart required guidance for both manufacturers and adept authorities enabling them to superintend cases coherently and appropriately. Materiovigilance programme of India (MvPI) was launched by the Drug Controller General of India at the Indian Pharmacopoeia commission (IPC) in Ghaziabad in 2015. The main purpose of this initiative is to monitor adverse events associated with medical devices in order to generate safety data, create awareness among the various stakeholders, and prescribe best practices for patient safety. Whilst the reforms in regulations have proposed policies and designs to elucidate, consolidate and accelerate the processes involved in manufacturing and importing medical devices to India, they consistently carry their challenges and limitations. To eliminate such complications the guidelines and regulations are anticipated to be implemented appropriately with the efficacious conclusion. India has been evident in matching with advancements in the World Medical Device regulation scenario, the current review at hand takes upon the question of 'how successful has it been so far'?
\end{abstract}

\section{Introduction}

The term 'Medical device' represents any instrument, apparatus, implant, in vitro reagent, or software intended for disease diagnosis or treatment in humans [1-3]. Medical devices vary in both their intended use and indications for use. Few examples of medical devices commonly used in clinical practice include cardiac stents, glucometers, internal prosthetic replacements, automated external defibrillator (ADE), orthopaedic implants, disposable hypodermic needles, and syringes, etc [3]. The demand for these devices is predicted to rise due to increased incidence of metabolic ailments like stroke, obesity, diabetes, and cancer worldwide. Nonetheless, med- ical devices contribute to patient care excessively but, like drugs, also contain possible threats and risks on the application and/or implementation. A few such examples include electrical burns to a patient due to ADE malfunctioning [3], presence of metal particles in the blood and soft tissue due to wearing down of metal on metal hip replacement device, etc [4]. In multiple instances, some devices were recalled because of the risks and damages they caused to users [3, 5-7]. Therefore, a proper scheme intended to maintain the standard and safety of devices used in health care is important.

The global market for medical devices increased to an estimated 380 Billion US \$ in 2016 in comparison to only 260 billion US\$ 
in 2006. India is among the top twenty medical device industries globally which has contributed 3 billion US \$ to this sector. However, there has been no proper system for registering medical device adverse events (MDAE) or tracking the safety record of medical devices in India. It has been largely dependent on data from developed countries. A systematic and well-framed vigilance system is therefore recommended for a strong medical device regulatory structure. It is also crucial to determine and evaluate the associated risks and benefits at every stage of device development [8]. Further, regulators or manufacturers must ensure the protection of patient's health by preventing its recurrences in the future and that void can be filled by the concept of Materiovigilance [2]. Also, the true public health burden of adverse events associated with medical devices is unknown [9].

Materiovigilance implies close monitoring of any undesirable event occurring because of a medical device by collecting, reporting, and estimating unwanted events. It also includes responding to the event by regulatory agencies and ensuring safety and corrective measures to be taken during the post-marketing stage. The primary goal behind Materiovigilance is to improve the assurance of the health safety of the patients, users, and others by decreasing the reoccurrence of an event $[2,10,11]$. The review presents a comprehensive overview of the current regulations and practices over the reporting of medical device-associated adverse events in India.

\section{Medical Device Rule in India: Devices are Different than Drugs}

Under the Drug and Cosmetic Act, 1940, medical devices were regulated as drugs (pharmaceutical products) in India prior to the introduction of the Medical Device Rules 2017 which came into force on 1 January 2018. Hence, the differentiation between medical devices and pharmaceutical products was needed. The central drug standard control organization (CDSCO) categorized devices from time to time and displayed them on their official website. The classification list provided by Medical Device Rule 2017 mentioned in - Table 1.

\section{Materiovigilance in India}

Medical Devices in India are presently regulated by the CDSCO which in turn is controlled by the Ministry of Health and Family Welfare, Government of India. The Medical Devices Regulation Bill (MDRB), which was introduced in 2006 by the Ministry of Science

- Table 1 Device classification as per Medical device rule 2017

\begin{tabular}{|l|l|l|}
\hline $\begin{array}{l}\text { Device risk } \\
\text { class }\end{array}$ & Type of risk & Examples \\
\hline Class A & Low-risk & $\begin{array}{l}\text { Bolster suture, Alcohol } \\
\text { swaps, Nasopharyngeal } \\
\text { catheter }\end{array}$ \\
\hline Class B & Low-moderate & $\begin{array}{l}\text { Disinfectants, Intravenous } \\
\text { catheter, Rectal catheter }\end{array}$ \\
\hline Class C & Moderate-high & $\begin{array}{l}\text { Biliary stents, Bone } \\
\text { cement, Imaging catheter }\end{array}$ \\
\hline Class D & High & $\begin{array}{l}\text { Coronary stent, Heart } \\
\text { valve, Copper-T }\end{array}$ \\
\hline
\end{tabular}

and Technology, is aimed towards the reinforcement of medical devices related laws and the establishment of Medical Device Regulatory Authority of India (MDRA). The prime objective of this bill was to create and cement a system for the regulation of safety, quality and accessibility of Indian medical devices which would operate nationally [1]. Additionally, the Drugs and Cosmetics (Amendment) Bill, 2013 was brought in the scenario of regulatory measures which comprised a whole distinct chapter on regulatory limitations for import, export, sale, manufacture and distribution of medical devices in India. It briefs about the procedure to be followed for obtaining import license and registration etc, [1, 2].

After a strong need for a robust reporting structure of MDAE, on July 6, 2015, the Indian Pharmacopeia Commission has launched the MvPI. The objectives of MvPI are to track the adverse events associated with the use of medical devices, to generate safety data, create awareness among the different stakeholders, and recommend the best practices and interventions to improve the patient's safety by reducing the likelihood reoccurrence of an adverse event associated with the use of Medical Devices. Materiovigilance is the coordinated system of identification, collection, reporting, and analysis of any untoward occurrences associated with the use of medical devices and protection of patient's health by preventing its recurrences. Hence, MvPI helps to ascertain in the reduction in the probability of recurrence of such MDAEs and improvement in the quality of Health products [2, 3, 12-14].

\section{Applications of MvPI}

Prime Applications of MvPI:

1. To fabricate a structure for patient safety supervising.

2. Injuries \& impediments prevention.

3. To generate evidence-based statistics on medical device safety.

4. To aid CDSCO in the authoritative operations on medical device utilization and share conclusive reports with different stakeholders.

5. To come into view as national centre of eminence for materiovigilance schemes.

6. To put into effect restorative steps in order to inhibit possible adverse events in future.

\section{Materiovigilance Programme of India (MvPI): Scope and structure}

Indian pharmacopoeia commission at Ghaziabad serves as the national coordination center and Sree Chitra Tirunal Institute of Medical Sciences and Technology (SCTIMST) in Thiruvananthapuram acts as the collaborating center. The technical support is provided by the National Health System Resource Centre (NHSRC) in New Delhi. The purpose of these agencies is to study and follow MDAEs and enables dangerous ones to be withdrawn from the market. MvPI was envisaged as a nation-wide programme involving district hospitals, medical colleges and corporate healthcare institutions.

MvPI functions for evidence-based data generation on medical device safety, to exchange information with other stakeholders, to analyze the risk-benefit of Medical devices, to assist CDSCO (regulator) in making decisions on usage regulations of medical devices and set up an absolute national system of patient safety monitor- 
ing. The programme also aims to create awareness among healthcare professionals about the importance of reporting MDAEs $[2,3,14-16]$.

The constitution of Materiovigilance programme of India has been depicted in $\mathbf{F i g} \mathbf{1} \mathbf{1}$

Nationally, 10 medical colleges have been identified as Medical Device Monitoring Centers (MDMC) by the IPC that operates as National Coordination Centre (NCC), [2, 3] but now there are 26 MDMCs to which MDAEs are reported by the concerned healthcare personnel. MDMCs inspect failure mode effect, evaluate casualty and submit a monthly integrated report to the NCC [8]. A list of MDMCs is mentioned in $>$ Table 2. Presently, SCTIMST, Thiruvananthapuram is appointed as the NCC which then combines, analyzes and conducts signal detection on the reported data and share concluded information with the NCC. NCC works out the data received and communicates with CDSCO that functions as Regulator-MvPI regarding the required response. NCC also coordinates with all the stakeholders, combines the executive committee and executes group meetings. Other NCC responsibilities include preparation and circulation of Standard operating procedures, training manuals and newsletters. NHSRC serves as Technical support and resource centre and provides technical support to NCC [2,3].

\section{Stakeholders of MvPI}

1. All professionals including staff at IPC, SCTIMST NHSRC and all such institutions.

2. Medical device Monitoring Centre Officials.

3. CDSCO advisers \& staff.

4. All Healthcare Policy makers, specifically the ones concerned with Medical Device Policy.

5. Clinicians, clinical engineers, biomedical engineers, pharmacists, nurse in conjunction with hospital technology managers.

6. Medical device manufacturers advised by CDSCO.

7. Medical Technologists \& Innovators.
8. Importers \& Traders dealing in medical devices are also eligible to report specifically about their own products.

\section{Reporting System of the Medical Device- Associated Adverse Events}

\section{Who can report MDAEs?}

MDAEs can be reported to SCTIMST or NCC by healthcare professionals (physicians, pharmacists, dentists, nurses, biomedical engineers) and patients. Additionally, CDSCO recognized medical device manufacturers or importer trader can also report AEs specific for their device directly to SCTIMST or NCC, Thiruvananthapuram, Kerala, India [17, 18].

\section{What to Report?}

All types of MDAEs (known or unknown, serious or non-serious, rare, or frequent) regardless of established causal relationship can be reported. Details of $A E$ include incident description, medical device description, and associated risk with a medical device to patient/user, any possible risk associated with previous use can be documented in MDAEs reporting form $[15,17,18]$.

\section{How and Whom to Report MDAEs?}

MDAEs can be reported to MAMCs by using the MDAE reporting form which is available on the official website of IPC (www.ipc.gov. in). Research associates from MDMCs then submit this duly filled form to NCC via email on mvpi@sctimst.ac.in. Alternatively, NCCPvPI toll-free helpline no. 1800-180-3024 can also be used for MDAEs reporting. All the reported cases at NCC are finally reviewed and assessed and forwarded to WHO-Uppsala Monitoring Centre (WHO-UMC) $[15,17,18]$.

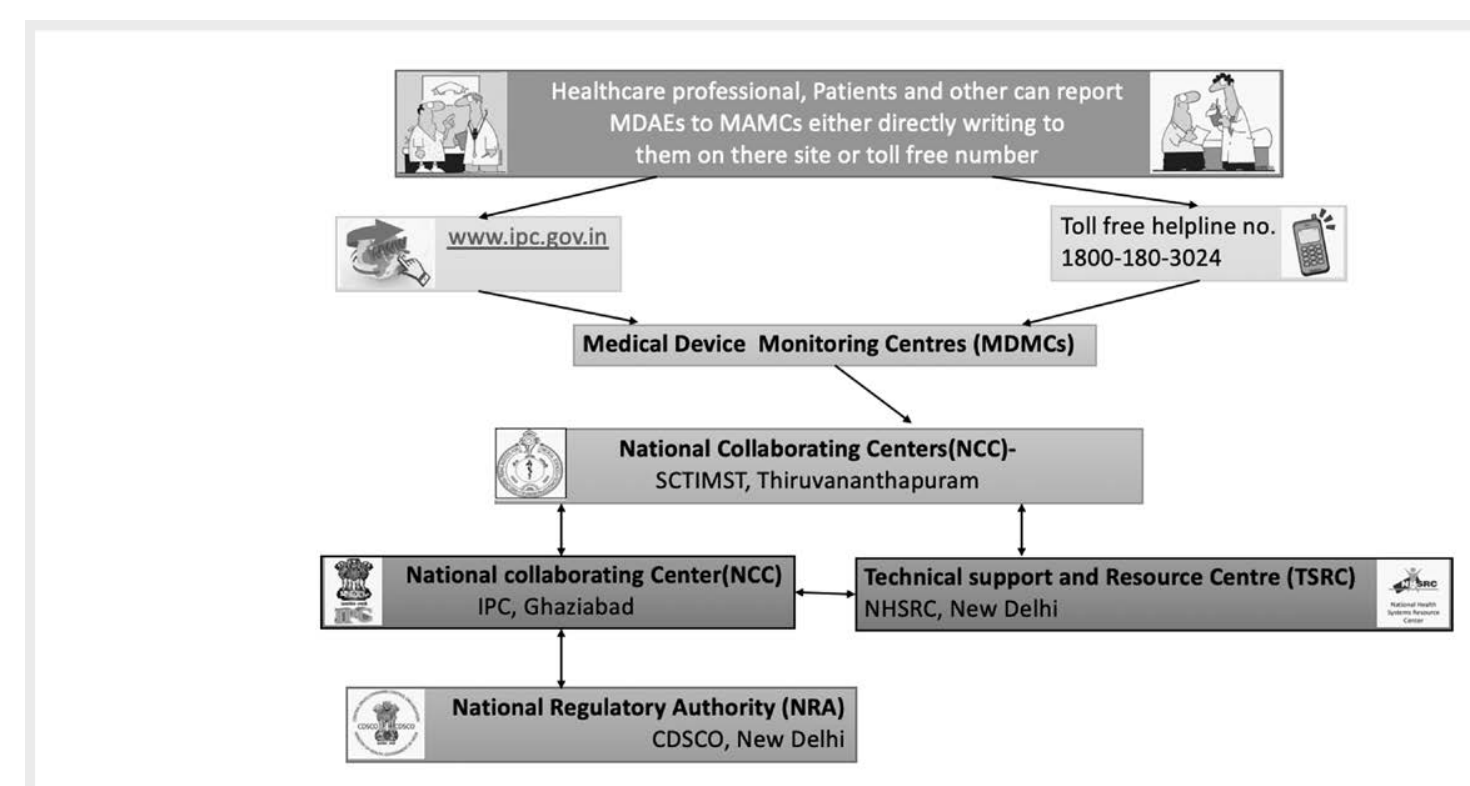

-Fig. 1 Constitution of Materiovigilance programme of India. 
- Table 2 List of MDMCs

\begin{tabular}{|c|c|c|c|}
\hline S. No. & MDMC Name \& Address & Status & $\begin{array}{l}\text { Year of } \\
\text { Recognition }\end{array}$ \\
\hline 1 & $\begin{array}{l}\text { Dept. of Oral and Maxillofacial Surgery, Maratha Mandal's Nathajirao G Halgekar Institute of } \\
\text { Dental Sciences \& Research centre Belagavi Karnataka - } 590010\end{array}$ & Non Government & 2019 \\
\hline 2 & $\begin{array}{l}\text { Lady Hardinge Medical College Department of Pharmacology, C-604 Shaheed Bhagat Singh, } \\
\text { Road, DIZ Area, Connaught Place, New Delhi, Delhi } 110001\end{array}$ & Government & 2019 \\
\hline 3 & $\begin{array}{l}\text { Department of Pharmacology, Hamdard Institute of Medical Sciences \& Research Jamia } \\
\text { Hamdard, New Delhi - } 110062\end{array}$ & Non Government & 2019 \\
\hline 4 & $\begin{array}{l}\text { School of Tropical Medicine Department of Clinical \& Experimental Pharmacology, } 108 \text { Chitta } \\
\text { Ranjan Avenue, Kolkata - } 700073\end{array}$ & Government & 2019 \\
\hline 5 & $\begin{array}{l}\text { Yashoda Super Speciality Hospital H1,26,27, Kaushambi, Near, H-1 Metro, Kaushambi, } \\
\text { Ghaziabad, Uttar Pradesh } 201001\end{array}$ & Non Government & 2019 \\
\hline 6 & $\begin{array}{l}\text { Frontier Lifeline Hospital Pvt Ltd, R30-C, Ambattur Industrial Estate Road, Mogappair, } \\
\text { Chennai, Tamilnadu - } 600101\end{array}$ & Non Government & 2019 \\
\hline 7 & $\begin{array}{l}\text { Dr Sampurnanand Medical College, Residency Road, Near Sriram Excellency Hotel, Opposite } \\
\text { Petrol Pump, Sector-D, Shastri Nagar, Jodhpur, Rajasthan } 342003\end{array}$ & Government & 2019 \\
\hline 8 & Dept. of Pharmacology, All India Institute of Medical Science, Patna, Bihar-801507 & Government & 2019 \\
\hline 9 & $\begin{array}{l}\text { Dept. of Pharmacy Practice, St. James College of Pharmaceutical Sciences, Chalkudy, Thrissur, } \\
\text { Kerala-680307 }\end{array}$ & Non Government & 2019 \\
\hline 10 & $\begin{array}{l}\text { Biomdical wing, District Hospital Mavelikkara, Near mavelikara Pandalam Road, Thazhakkara, } \\
\text { Mavelikara, Alappuzha, Kerala } 690102\end{array}$ & Government & 2019 \\
\hline 11 & $\begin{array}{l}\text { Dept. of Pharmacology, Veer Surendra Sai Institute of Medical Sciences and Research } \\
\text { (VIMSAR) Pg Chowk, Burla, Odisha } 768017\end{array}$ & Government & 2019 \\
\hline 12 & $\begin{array}{l}\text { Dept. of Pharmacology, SLN Medical College and Hospital, Janiguda, Koraput, Odisha } \\
764020 .\end{array}$ & Government & 2019 \\
\hline 13 & $\begin{array}{l}\text { Dept. of Pharmacology, Konaseema Institute Of Medical Science Amlapuram Andra Pradesh } \\
\text { - } 533201\end{array}$ & Non Government & 2019 \\
\hline 14 & $\begin{array}{l}\text { Dept. of Pharmacology, All India Institute of Medical Sciences, Saket Nagar, Bhopal, Madhya } \\
\text { Pradesh } 462020\end{array}$ & Government & 2019 \\
\hline 15 & $\begin{array}{l}\text { Mysore Medical College and Research Institute, Irwin Road, Next to Railway Staion, Mysuru, } \\
\text { Karnataka } 570001 \text { (Affiliated hospitals: K.R. Hospital; Cheluvamba Hospital; PKTB Hospital) }\end{array}$ & Government & 2018 \\
\hline 16 & $\begin{array}{l}\text { College of Pharmacy, Sri Ramakrishna Institute of paramedical Sciences, 395,Sarojini Naidu } \\
\text { Rd,Sidhapur,Coimbatore641044 }\end{array}$ & Non Government & 2018 \\
\hline 17 & $\begin{array}{l}\text { Department of Quality Systems Royal Care Super Speciality Hospital, SF No:554/555, } \\
\text { Neelambur Village, Sulur Taluk,CBE,Tamilnadu-641062 }\end{array}$ & Non Government & 2018 \\
\hline 18 & $\begin{array}{l}\text { Department of Biomedical Engineering, National Institute of Mental Health \& Neuro Sciences } \\
\text { (NIMHANS), Hosur Road, Lakkasandra, Wilson Garden, Bengaluru, Karnataka } 560029\end{array}$ & Government & 2017 \\
\hline 19 & $\begin{array}{l}\text { Department of Biomedical Engineering, Sanjay Gandhi Post Graduate Institute of Medical } \\
\text { Science, Luknow, Uttar Pradesh }\end{array}$ & Government & 2017 \\
\hline 20 & $\begin{array}{l}\text { Jawaharlal Institute of Postgraduate Medical Education and Research (JIPMER), Dhavantri } \\
\text { Nagar, Gorimedu, Puducherry-605006 }\end{array}$ & Government & 2017 \\
\hline 21 & $\begin{array}{l}\text { Narayana Health, NH Health City,258/A, Bommasandra Industrial Area, Anekal Taluk, Hosur } \\
\text { Road, Bangalore-560099 (Affiliated hospitals: Narayana Institute of Cardiac Sciences; } \\
\text { Mazumadar Shaw Medical Center) }\end{array}$ & Non Government & 2016 \\
\hline 22 & $\begin{array}{l}\text { Postgraduate Institute of Medical Education and Research, Room no. 4043, 4th Floor, } \\
\text { PGIMER, Sector-12, Chandigarh-160012 }\end{array}$ & Government & 2016 \\
\hline 23 & $\begin{array}{l}\text { Department of Pharmacology, Dayanand Medical College and Hospital, Ludhiana, Pun- } \\
\text { jab, } 141001\end{array}$ & Non Government & 2016 \\
\hline 24 & $\begin{array}{l}\text { Department of Pharmacology, All India Institute of Medical Sciences (AlIMS), Ansari Nagar } \\
\text { East, Gautam Nagar, New Delhi-110029 }\end{array}$ & Government & 2016 \\
\hline 25 & $\begin{array}{l}\text { Glocal Group of hospitals, } 3 \text { B 207, Eco-space Business Park action Area II, New town } \\
\text { Rajarhat, Kolkata- } 700156\end{array}$ & Non Government & 2016 \\
\hline 26 & $\begin{array}{l}\text { Department of Biomedical Engineering, Christian Medical College (CMC), Thorapadi } \\
\text { Vellore- } 6323004\end{array}$ & Government & 2016 \\
\hline
\end{tabular}




\section{Reporting of MDAEs to NCC-MvPI IPC}

Since the inception of MvPI, the IPC received and evaluated more than 1931 AEs involving medical devices till October 2019. Out of which 1277 (66.17\%) were serious and rest were non-serious. Reporting of MDAEs in India significantly increased post-2017, after the introduction of medical device rules and friendly reporting procedures. These AEs were reported by various authorities such as marketing authorization holders (1439 cases), MDAEs monitoring centers (419 cases), ADRs monitoring centers (70), and by consumers itself (3 cases) [8]. AEs associated with commonly used medical devices are listed in $>$ Table 3 .

\section{Global Structure of Medical Device Adverse Event Regulations}

India has been recently emerged with medical device related adverse event regulation, which is still in progress and gradually will be updated with more comprehensive guidelines. However, major regulatory agencies such as USA, EU and China have well-established AE reporting guidelines for medical devices. Comparisons between different countries of Medical Device Regulations are listed in $>$ Table 4.

\section{USA}

Centre for Devices and Radiological Health regulates Medical devices in the USA operating under the authority of US Food and Drug Administration (FDA). Classification and regulation of Medical devices are based on the level of convolution and risk to the public. Three categories are suggested for Medical devices by the FDA regulatory classifications scheme, which are: Class I, Class II \& Class III, belonging to lower, moderate and higher risks presented by devices and the degree of control FDA finds necessary to legally market the device, respectively $[1,6,19]$.

Manufacturers and importers of medical devices are obliged to report malfunctioning of a device or death/injury caused by it in a 30 day time window to FDA in accordance with medical device regulations. In case of hospitals, nursing homes \& outpatient diagnostic facilities coming across serious injury/death cases, reports are to be filed to the manufacturer as well as FDA under 10 days of event. FDA also prescribes specific events that are needed reporting under 5 day time window in order to avoid potential risks [20].

\section{European Union}

European Union abides by a four category classification when it comes to classifying Medical Devices based on risk associated, alike

- Table 3 Adverse events associated with medical device

\begin{tabular}{|l|l|c|}
\hline S. No & Medical Device & $\begin{array}{l}\text { No. of reported } \\
\text { MDAEs }\end{array}$ \\
\hline 1 & Cardiac Stents & 926 \\
\hline 2 & Intrauterine contraceptive devices & 226 \\
\hline 3 & Orthopedic Implants & 179 \\
\hline 4 & Catheters & 76 \\
\hline 5 & Intravenous Cannulae & 75 \\
\hline 6 & Other Devices & 449 \\
\hline
\end{tabular}

USA. Devices are divided into Class I (combining Is \& Im as well), Ila, IIb and Class III. A marking denoted by the initials 'CE' is a confirmatory marking required by all Medical Devices to be printed on them or their sterile packaging in some cases before they are subjected to the market. Authorities appointed by the manufacturer are accountable for the agreement of the device with regulations $[1,19]$.

Manufacturers are responsible for reporting risks associated with medical devices at post marketing surveillance. State of Europe necessitates manufacturers to have their own reporting systems for medical device related adverse events reporting. On violation of event reporting time limits or under reporting of events, state can impose massive monetary fines as well jail sentences on responsible individual/organization [21].

\section{China}

The regulation of Medical Devices operates under the authority of central State Food and Drug Administration (SFDA) as well as the local provincial supervision in China. SFDA evaluation body comprises of its own dedicated evaluation centers as well as expert technical committees where medical devices are subjected to additional clinical evaluation. It is the state's responsibilities to collect, analyse, evaluate and control adverse events related data. Any organization/individual is authorized to report an adverse or suspected adverse event to the Food and Drug Administration Department in China [22]. China follows a risk based regulatory system for Medical Devices classifying them in Class I, II \& III based on the risks involved. From this three-class categorization Class II \& III devices are subjected to additional clinical evaluation taking place in SFDA appointed hospitals [1].

\section{Future Direction}

The main objective of MvPI is to improve the protection of the health and safety of patients, healthcare professionals, and others by reducing the likelihood of reoccurrence of an adverse event associated with the use of medical devices. Taking into consideration the present scenario of the healthcare system in India, strict vigilance is needed to safeguard the health and safety of the patients. The monitoring of medical devices is equally important like drugs to ensure patient safety. MvPI process also works as a tool for awareness amongst the patients, healthcare professionals, and others for reporting adverse events related to medical devices. This will also nurture the reporting culture among individuals. MvPI will also help to keep an eye on manufacturers, whether they are working on the issues or not. Studding adverse effects related to medical devices will also serve as a great tool in public health. A long term goal of MvPI is to make reporting mandatory for medical device manufacturers [23].

\section{Conclusion}

The MvPI is still in the infancy stage in India and is growing firmly which will surely play a critical role in preventing MDAEs amongst the Indian population. However, in countries with established regulation, precise device tracking and devising proper penalties in conjunction with firm reporting guideline and limiting forgeries have persuaded manufacturers to develop quality devices. In India, 
- Table 4 Reporting guideline of Medical device associated adverse events in USA, Europe, China and India.

\begin{tabular}{|c|c|c|c|c|}
\hline & USA [20] & Europe [21] & China [22] & India [20] \\
\hline $\begin{array}{l}\text { Device } \\
\text { tracking }\end{array}$ & $\begin{array}{l}\text { Device tracking is done as post } \\
\text { marketing surveillance activity. } \\
\text { Certain implantable devices are } \\
\text { subjected to tracking. } \\
\text { Manufacturer is required to } \\
\text { produce information within } 3 \text { or } \\
10 \text { days depending upon the } \\
\text { position of a device. (If it hasn't/ } \\
\text { has been distributed to a patient, } \\
\text { respectively) }\end{array}$ & $\begin{array}{l}\text { European Medicines Agency (EMA) } \\
\text { looks after device tracking through } \\
\text { Adverse Incident Tracking System } \\
\text { (AITS). } \\
\text { Device related incidents are } \\
\text { entered in AITS database via a user } \\
\text { reporting system followed by the } \\
\text { allocation of a reference number. } \\
\text { As per investigation, the adverse } \\
\text { incident is allocated into one of the } \\
\text { five (urgent in depth, in depth, } \\
\text { standard, information \& others) } \\
\text { investigation categories. } \\
\text { Manufacturer or authorized } \\
\text { representative is responsible to } \\
\text { track incident reports. }\end{array}$ & $\begin{array}{l}\text { Enterprises engaged in wholesale of } \\
\text { Class II/III medical devices or in retail } \\
\text { of Class III medical devices should } \\
\text { establish a sales recording system. } \\
\text { The items to be recorded are: } \\
\text { (a) Name, specification, model and } \\
\text { quantity of medical device; } \\
\text { (b) Production lot number, period of } \\
\text { validity, and sales date of medical } \\
\text { device; } \\
\text { (c) Name of manufacturing } \\
\text { enterprise; } \\
\text { (d) Name, address and contact } \\
\text { information of the supplier or } \\
\text { purchaser; } \\
\text { (e) No. of relevant licensing } \\
\text { documents. }\end{array}$ & $\begin{array}{l}\text { Medical devices } \\
\text { are required to } \\
\text { feature lot/ } \\
\text { batch numbers } \\
\text { on their label. }\end{array}$ \\
\hline $\begin{array}{l}\text { Adverse } \\
\text { event } \\
\text { reporting }\end{array}$ & $\begin{array}{l}\text { Manufacturers and importers are } \\
\text { required to report serious injury/ } \\
\text { death within } 30 \text { days of its } \\
\text { discovery as per medical device } \\
\text { reporting (MDR) regulations by } \\
\text { FDA. } \\
\text { Manufacturers are required to } \\
\text { report malfunctions less than } 30 \\
\text { day time period since discovery. } \\
\text { User facilities such as hospital, } \\
\text { nursing home, outpatient } \\
\text { diagnostic facility etc. are to } \\
\text { report serious injuries and deaths } \\
\text { within } 10 \text { work days to both FDA } \\
\text { and manufacturer. }\end{array}$ & $\begin{array}{l}\text { Manufacturers are responsible for } \\
\text { reporting risks associated with the } \\
\text { medical devices at post marketing } \\
\text { surveillance. }\end{array}$ & $\begin{array}{l}\text { The state is responsible for the } \\
\text { collection, analysis, evaluation and } \\
\text { control adverse events related data. } \\
\text { Any organization /individual can } \\
\text { report an adverse or suspected } \\
\text { adverse event to the Food and Drug } \\
\text { Administration Department. }\end{array}$ & $\begin{array}{l}\text { Adverse event } \\
\text { can be reported } \\
\text { by the } \\
\text { manufacturer, } \\
\text { importer and } \\
\text { distributer. }\end{array}$ \\
\hline $\begin{array}{l}\text { Timeline of } \\
\text { reporting }\end{array}$ & $\begin{array}{l}\text { 30-days to report death, serious } \\
\text { injuries and malfunctions. } \\
\text { 5-days to report an event } \\
\text { designated by FDA or that } \\
\text { requires remedial action to } \\
\text { prevent an unreasonable risk. } \\
\text { 10-days to report death and } \\
\text { serious injuries by user facilities. } \\
\text { Summary reports on quarterly } \\
\text { basis. } \\
\text { Annual reports on death and } \\
\text { serious injuries. }\end{array}$ & $\begin{array}{l}\text { Serious injury or death reports are } \\
\text { to be filed to Competent } \\
\text { Authorities under } 10 \text { days. } \\
\text { Firms have } 30 \text { calendar days to file } \\
\text { reports. } \\
\text { Serious public health threats have a } \\
\text { two-day deadline. }\end{array}$ & $\begin{array}{l}\text { Healthcare providers or device } \\
\text { manufacturers must report a Serious } \\
\text { Adverse Events (SAE) within } 15 \text { days } \\
\text { of its occurrence. } \\
\text { If the SAE results in death, it must be } \\
\text { reported within } 5 \text { days. } \\
\text { Normal adverse events must be } \\
\text { reported within } 30 \text { days. }\end{array}$ & $\begin{array}{l}\text { Immediate } \\
\text { reporting as } \\
\text { soon as } \\
\text { possible. }\end{array}$ \\
\hline $\begin{array}{l}\text { How to } \\
\text { report }\end{array}$ & $\begin{array}{l}\text { Form } 3500 \mathrm{~A} \text { or an electronic } \\
\text { equivalent. } \\
\text { Form } 3419 \text { for reporting annual } \\
\text { user facility report. }\end{array}$ & $\begin{array}{l}\text { Manufacturers must have a system } \\
\text { for recording and reporting of } \\
\text { incidents and field safety corrective } \\
\text { actions. }\end{array}$ & $\begin{array}{l}\text { Manufacturers use National Medical } \\
\text { Device Adverse Event Monitoring Plat- } \\
\text { form for reporting adverse events. }\end{array}$ & $\begin{array}{l}\text { A reporting } \\
\text { format has been } \\
\text { prepared by } \\
\text { MvPI. } \\
\text { These forms are } \\
\text { duly signed and } \\
\text { can be sent to } \\
\text { nearest MDMC } \\
\text { or can be } \\
\text { directly sent to } \\
\text { the National } \\
\text { Collaborating } \\
\text { Center. }\end{array}$ \\
\hline
\end{tabular}


> Table 4 Continued

\begin{tabular}{|c|c|c|c|c|}
\hline & USA [20] & Europe [21] & China [22] & India [20] \\
\hline Penalties & $\begin{array}{l}\text { FDA can order a product recall, } \\
\text { seize product as well as refuse } \\
\text { import of products in violation of } \\
\text { FFDCA. } \\
\text { If necessitated FDA can have } \\
\text { courts issue injunction or } \\
\text { prosecute law violating company } \\
\text { individuals. } \\
\text { Criminal penalties including } \\
\text { prison sentences can solicited if } \\
\text { required. }\end{array}$ & $\begin{array}{l}\text { Number of judicial regimens act on } \\
\text { incident reporting time limit } \\
\text { violation or under reporting in EU } \\
\text { member states. } \\
\text { Hefty penalty amounts as well as } \\
\text { jail sentences are sought on } \\
\text { repetition or serious first-time law } \\
\text { violation by regulators in Germany, } \\
\text { France and UK. }\end{array}$ & $\begin{array}{l}\text { Penalties, if medical devices are being } \\
\text { manufactured and operated illegally: } \\
\text { If value of device is less than RMB } \\
10000 \text {, a penalty higher than RMB } \\
50000 \text { but lower than RMB } 100000 \\
\text { should be imposed additionally. } \\
\text { If value is higher than RMB } 10000 \text {, a } \\
\text { penalty of more than } 10 \text { times but } \\
\text { less than } 20 \text { times of the value of the } \\
\text { goods should be imposed addition- } \\
\text { ally. } \\
\text { Any Medical Device permit applica- } \\
\text { tion from gross violators must be } \\
\text { rejected under } 5 \text {-year time period. } \\
\text { Penalty above RMB } 50000 \text { but less } \\
\text { than RMB } 100000 \text { to be imposed and } \\
\text { no application for medical device } \\
\text { related license or permit acceptance } \\
\text { within } 5 \text { years if any document is } \\
\text { obtained by providing false } \\
\text { information or taking other deception } \\
\text { means. } \\
\text { In case of falsifying, altering, buying } \\
\text { and selling, leasing, and borrowing } \\
\text { relevant medical device licensing } \\
\text { certificate : } \\
\text { For illegal income of less than RMB } \\
10000 \text {, a penalty above RMB } 10000 \\
\text { but less than RMB } 30000 \text { should be } \\
\text { imposed additionally. } \\
\text { For illegal income of more than RMB } \\
10000 \text {, a penalty at more than } 3 \\
\text { times and less than } 5 \text { times should be } \\
\text { imposed additionally. } \\
\text { For violation of security regulations, } \\
\text { punishment is solicited according to } \\
\text { the public security organ. }\end{array}$ & $\begin{array}{l}\text { A device's, } \\
\text { which is not } \\
\text { compliant to } \\
\text { regulations, } \\
\text { individual } \\
\text { manufacturing, } \\
\text { sale or selling to } \\
\text { buyers } \\
\text { preconception is } \\
\text { eligible for fine } \\
\text { extending to } \\
\text { five lakhs } \\
\text { Rupees or } \\
\text { imprisonment } \\
\text { which may } \\
\text { extend to one } \\
\text { year or both. }\end{array}$ \\
\hline
\end{tabular}

it is expected that the effective implementation of MvPI will defend the safety of the device and prevent the risk of adverse effects at user level. Furthermore, these programs generate independent, evidence-based recommendation on the safety of medical devices and communicate the findings to all key stakeholders. In addition to this, the comprehension of regulatory reforms in India will prove to be critical in various company's attempts to penetrate the Indian medical market.

\section{Funding}

This review did not receive any specific grant from funding agencies in the public, commercial or non-for profit sectors.

\section{Conflict of Interest}

The authors declare that they have no conflict of interest.

\section{References}

[1] Gupta SK. Medical Device Regulations: A Current Perspective. Journal of Young Pharmacists 2016; 8: 1

[2] Rani S, Singh K. Materiovigilance: An emerging discipline. Int ] Sci Res 2018; 7: 15-16

[3] Meher BR. Materiovigilance: An Indian perspective. Perspectives in Clinical Research 2018; 9: 175

[4] The Inidan Express, How Johnson and Johnson hip implants system went wrong. Available from https://indianexpress.com/article/ explained/johnson-and-johnson-how-hip-implants-went-wrong-jpnada-5331779, Accessed on November 11, 2019 
[5] Jarow JP, Baxley JH. Editors Medical Devices: US Medical Device regulation. Urologic Oncology: Seminars and Original Investigations. 2015; Elsevier

[6] Gupta P, Janodia MD, Jagadish PC et al. Medical device vigilance systems: India, US, UK, and Australia. Medical Devices (Auckland, NZ) 2010; 3: 67

[7] Hauser RG. Here we go again-another failure of postmarketing device surveillance. New England Journal of Medicine 2012; 366: 873-875

[8] Shukla S, Gupta M, Pandit S et al. Implementation of adverse event reporting for medical devices. Bull World Health Organ 2020; 98 : 206-211

[9] Hefflin B], Gross TP, Schroeder TJ. Estimates of medical device-associated adverse events from emergency departments. American Journal of Preventive Medicine 2004; 27: 246-253

[10] Materiovigilance programme of India. 2019; p. 6. Available from: http://www.mvpi.co.in/newsletter6/newsletter6.html\#page/1, Accessed on December 21, 2019

[11] Datta P, Mukhopadhyay I, Selvaraj S. Medical devices manufacturing industry in India: Market structure, import intensity and regulatory mechanisms. ISID-PHFI Collaborative Research Centre, Institute for Studies in Industria. 2013

[12] Mandal S, Mandal M. Evolution of Pharmacovigilance Programme: Present status in India. Pharma Times 2017; 49: 31-36

[13] Kalaiselvan V, Srivastava S, Singh A et al. Pharmacovigilance in India: Present scenario and future challenges. Drug Safety 2019; 42: 339-346

[14] Mal DK, Ehsan I, Mukherjee B. MATERIOVIGILANCE and HAEMOVIGILANCE. Available from; https://www.asianhhm.com/healthcare-management/materiovigilance-haemovigilance Accessed on January 9, 2020
[15] Materiovigilance Programme of India (MvPI), Indian Pharmacopoeia Commission, 2015 Available from; https://ipc.gov.in/images/pdf/ File572.pdf, Accessed Dec, 2019

[16] Singh K, Kanase H. Pharmacovigilance programme of India: The beginning, current status and recent progress. Adv Pharmacoepidemiol Drug Saf 2017; 6: 1-4

[17] Kumar P, Kalaiselvan V, Kaur I et al. Materiovigilance programme of India (MVPI): A step towards patient safety for medical devices. Eur J Biomed Pharm Sci 2016; 12: 497-501

[18] Kalaiselvan V, Mishra P, Singh GN. Helpline facility to assist reporting of adverse drug reactions in India. WHO South-East Asia Journal of Public Health 2014; 3: 194

[19] Lamph S. Regulation of medical devices outside the European Union. Journal of the Royal Society of Medicine 2012; 105 (1_suppl): 12-21

[20] Gupta P, Janodia MD, Jagadish PC et al. Medical device vigilance systems: India, US, UK, and Australia. Medical Devices (Auckland, NZ) 2010; 3: 67

[21] European Commission Medical Device Regulation (MDR). Regulation (EU) 2017/745 of the European Parliament and of the Council of 5 April 2017 on Medical Devices. Available from: https://eurlex.europa. eu/legal-content/EN/TXT/PDF/?uri = CELEX:32017R0745, Accessed on April 7, 2020

[22] China NMPA Medical Device Regulations. Available from https://www. emergobyul.com/resources/regulations-china, Accessed on April 7, 2020

[23] Materiovigilance Programme of India (MvPI) Indian Pharmacopoeia Commisssion 2015. Available from: http://www.mvpi.co.in/newsletter6/newsletter6.html\#page/1, Accessed on October 26, 2019 